\title{
CORRECTION
}

\section{Correction to: Comparative study of codon usage profiles of Zingiber officinale and its associated fungal pathogens}

\author{
Suruchi Gupta ${ }^{1} \cdot$ Ravail Singh $^{1,2,3}$ (]) \\ Accepted: 11 August 2021 / Published online: 25 August 2021 \\ c) Springer-Verlag GmbH Germany, part of Springer Nature 2021

\section{Correction to: \\ Molecular Genetics and Genomics (2021) 296:1121-1134 \\ https://doi.org/10.1007/s00438-021-01808-8}

In the original published article, the corresponding author was processed incorrectly. The actual corresponding author of the article is Prof. Ravail Singh now this has been corrected.

The original article has been updated.

Publisher's Note Springer Nature remains neutral with regard to jurisdictional claims in published maps and institutional affiliations.

The original article can be found online at https://doi.org/10.1007/ s00438-021-01808-8.

Ravail Singh

rubail2010@gmail.com; ravail@iiim.ac.in

Suruchi Gupta

guptasurruchi@gmail.com

1 Plant Biotechnology Division, CSIR-Indian Institute

of Integrative Medicine, Jammu 180001, India

2 Academy of Scientific and Innovative Research (AcSIR), Jammu 180001, India

3 DZMB Senckenberg am Meer, Wilhelmshaven, Germany 